\title{
Kluczowe zagadnienia dotyczace projektowania i realizacji programów polityki zdrowotnej
}

\author{
Monika Patyna ${ }^{1}$ \\ Aneta Płusa ${ }^{2}$ \\ Anna Ziębińska
}

${ }^{1}$ Biuro Prezesa, Agencja Oceny Technologii Medycznych i Taryfikacji
${ }^{2}$ Dział Analiz i Strategii, Agencja Oceny Technologii Medycznych i Taryfikacji

Adres do korespondencji: Anna Ziębińska, Biuro Prezesa, Agencja Oceny Technologii Medycznych i Taryfikacji, ul. Przeskok 2,00-032 Warszawa, mailto:sekretariat@aotm.gov.pl

\section{Abstract}

The design, assessment, implementation, monitoring and evaluation of health policy programs

Health policy programs (HPP) are since 2004 one of the available paths of implementing public health tasks by local government units (LGUs). The design, assessment, implementation, monitoring and evaluation of HPP is regulated by the Act on the provision of health services financed from public funds. In 2009 an obligation to receive opinions on HPP projects from the Agency for Health Technology Assessment and Tariffs (AOTMiT, agency) has been introduced. Considering the increasing trend of HPP projects numbers sent for opinionizing by the Agency, this form of healthrelated activity is more frequently and willingly chosen by local government units. The experience of both LGUs and the Agency related to previously executed HPP in Poland indicates, that despite statutory changes and attempts to clarify the entries regarding this form of public health tasks in Poland, questions and doubts regarding the design, assessment and implementation of HPP still occur. Another issue discussed by the experts is whether HPP should become a mandatory task of local governments or whether they only supplement the public health system. In addition, an important subject of discussion by public health experts concerns the evaluation of health policy programs. There is an emphasis on the importance of designing HPP in a way that ensures implementation and performing actions that bring long-term health effects in the population. It also seems important to support this form of local governments activity in both substantive and financial terms. The Agency is one of the institutions that has an important role to play in supporting local government units in developing HPP projects of the highest quality, which has a direct impact on their effectiveness, satisfying health needs and improving the health of the population.

Key words: health policy program (HPP), Iocal government units (LGUs), projects, assessment, evaluation

Stowa kluczowe: program polityki zurowotnej (PPZ), jednostki samorzadu terytorialneyo (IST), projektowanie, ocena, ewaluacja

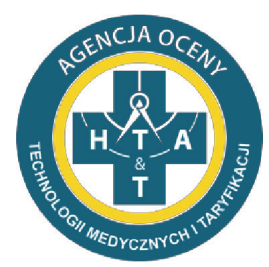

AGENCJA OCENY TECHNOLOGII MEDYCZNYCH I TARYFIKACJI

\section{Wprowadzenie}

W Polsce, zgodnie $\mathrm{z}$ obowiązującymi przepisami prawa, zadania z zakresu zdrowia publicznego mogą być realizowane przez wiele podmiotów i instytucji. Zadania te można prowadzić na różnych poziomach organizacyjnych, administracyjnych czy terytorialnych, jak również w ramach odmiennych, niewykluczających się

\begin{tabular}{|c|c|}
\hline $\begin{array}{l}\text { Rzeczpospolita } \\
\text { Polska }\end{array}$ & $\begin{array}{l}\text { Unia Europejska } \\
\text { Fundusz Spójności }\end{array}$ \\
\hline
\end{tabular}

wzajemnie form działalności. Formę i zakres realizacji zadań z zakresu zdrowia publicznego reguluje w głównej mierze ustawa o zdrowiu publicznym. Programy polityki zdrowotnej (PPZ) stanowią jeden z możliwych sposobów realizacji zadań z zakresu zdrowia publicznego przez jednostki samorządu terytorialnego (JST). Projektowanie, ocenę, realizację, monitorowanie i ewaluację PPZ regulują zapisy ustawy o świadczeniach 
opieki zdrowotnej finansowanych ze środków publicznych. Możliwość prowadzenia PPZ została wprowadzona w 2004 roku. Począwszy od 2009 roku wprowadzono obowiązek opiniowania projektów PPZ przez Agencję Oceny Technologii Medycznych i Taryfikacji (AOTMiT, dalej: agencja). W 2015 roku wprowadzono możliwość dofinasowania PPZ ze środków Narodowego Funduszu Zdrowia, przy czym od 2017 roku współfinansowanie dotyczy tylko interwencji znajdujących się w koszyku świadczeń gwarantowanych.

Doświadczenia zarówno JST, jak i agencji związane z dotychczas prowadzonymi PPZ w Polsce wskazują, iż mimo zmian ustawowych i prób doprecyzowania zapisów dotyczących tej formy realizacji zadań z zakresu zdrowia publicznego w Polsce nadal pojawiają się pytania i wątpliwości dotyczące projektowania i oceny oraz realizacji PPZ. W niniejszym artykule przedstawiono kluczowe kwestie dotyczące kolejnych etapów realizacji PPZ [1]: od problemów związanych z projektowaniem, poprzez zagadnienia związane $\mathrm{z}$ oceną, a następnie $\mathrm{z}$ realizacją programów, do tematu dotyczącego monitorowania i ewaluacji PPZ, w szczególności z punktu widzenia JST $\mathrm{i}$ agencji.

Warto podkreślić, iż środki finansowe przeznaczone na PPZ stanowią jedynie niewielki odsetek wydatków z zakresu zdrowia publicznego w Polsce. Według Raportu Najwyższej Izby Kontroli (NIK) z 2016 roku wydatki budżetowe JST na PPZ stanowią około $2 \%$ wydatków na ochronę zdrowia. Niemniej biorąc pod uwagę rosnący trend dotyczący liczby projektów PPZ przesyłanych do zaopiniowania przez agencję, są one coraz częściej i chętniej wybieraną formę aktywności samorządów w zakresie działań prozdrowotnych.

Mając na uwadze liczbę i rodzaj projektów PPZ, które były i są przedmiotem oceny agencji, można zauważyć, że najczęściej dotyczą one profilaktyki w postaci szczepień ochronnych mieszkańców JST (przeciw grypie, HPV), co wyjaśnia się faktem, iż są one stosunkowo łatwe do zaprojektowania i wdrożenia. Niemniej samorządy projektują i realizują PPZ obejmujące szeroki zakres problemów zdrowotnych, wśród których pojawiają się także projekty bardzo rozbudowane i złożone pod względem zakresu planowanych interwencji, jak również z budżetem sięgającym niejednokrotnie kilkudziesięciu mln zł.

Warto także zaznaczyć, iż zadania realizowane w ramach różnorodnych form działalności mogą dotyczyć tego samego zagadnienia/problemu zdrowotnego, ale mogą być rozbieżne pod kątem merytorycznym. Obowiązujące przepisy prawa nie w każdym przypadku narzucają konieczność bieżącej kontroli realizowanych zadań i monitorowania stanu tych prac. Uwagę należy również zwrócić na fakt, iż może wystąpić nierówność w dostępie do świadczeń, w konsekwencji czego działaniami nie zostanie objęta cała możliwa populacja docelowa. Jako przykład można wskazać zadania z zakresu profilaktyki uzależnień, zdrowia psychicznego czy prewencji nadwagi i otyłości.

Prawodawstwo polskie z jednej strony stwarza sytuację, która pozwala JST na wybór najlepszej, w danym momencie, w zależności od warunków i możliwości finansowych, formy realizacji zadań. Z drugiej strony jednak, ze względu na wielość możliwości wyboru form realizacji zadań z zakresu zdrowia publicznego, utrudnia podjęcie decyzji, szczególnie w odniesieniu do niejasności związanych z aspektami formalnoprawnymi i interpretacją obowiązujących przepisów prawa. Co więcej, brak jednoznacznych zapisów budzi ryzyko podwójnego finansowania świadczeń. Zgodnie z zasadą zakazu podwójnego finansowania niedozwolone jest zrefundowanie/rozliczenie, całkowite lub częściowe, danego kosztu dwa razy ze środków publicznych europejskich lub krajowych. Zatem JST, projektując i realizując zadania z zakresu zdrowia publicznego, są zobowiązane do stosowania różnych aktów prawnych, co może stanowić pewną barierę i ograniczenie aktywności JST w tym zakresie.

Należy wskazać, że do momentu nowelizacji ustawy o świadczeniach w 2017 roku agencja nie otrzymywała od JST informacji dotyczących zrealizowanych PPZ. Mając na uwadze brak danych sprawozdawczych w zakresie realizowanych PPZ, agencja dotychczas nie prowadziła szczegółowych analiz w przedmiotowym zakresie. Konieczność nadsyłania do agencji raportów końcowych z realizacji PPZ została wprowadzona wraz ze wspomnianymi zapisami nowelizującymi w 2017 roku. W raporcie końcowym oprócz odniesienia się do poszczególnych elementów programu JST będą mogły wskazywać także informacje o problemach, które wystąpiły w trakcie realizacji programu polityki zdrowotnej oraz o podjętych w związku z nimi działaniach modyfikujących. Powyższe umożliwi agencji przeprowadzanie analiz i weryfikację, czy działania zrealizowane w ramach PPZ przełożyły się na uzyskanie efektów zdrowotnych w populacji.

Natomiast w minionym okresie organy kontrolne lub nadzorujące JST, na podstawie danych sprawozdawanych przez JST, publikowały raporty i analizy dotyczące zadań z zakresu zdrowia publicznego realizowanych przez JST. W niniejszym artykule przedstawiono wyniki Raportu NIK z 2016 roku dotyczące realizacji PPZ przez JST oraz podsumowanie informacji ministra zdrowia o zrealizowanych lub podjętych zadaniach $\mathrm{z}$ zakresu zdrowia publicznego w latach 2016 i 2017. Odniesienie się do Raportu NIK oraz opracowania ministra zdrowia ma na celu zobrazowanie sytuacji $\mathrm{w}$ zakresie zdrowia publicznego w Polsce ze wskazaniem istotnych kwestii dotyczących PPZ realizowanych przez JST.

Mając także na uwadze dyskusje toczące się w gronie ekspertów zdrowia publicznego, w artykule odniesiono się do zagadnienia związanego z monitorowaniem i ewaluacją PPZ [2]. Według ekspertów to właśnie ta kwestia stanowi najbardziej istotny element projektu PPZ i wymaga właściwego zaplanowania i opracowania jeszcze przed etapem projektowania całego PPZ, tak aby wdrożenie programu doprowadziło do trwałych i widocznych efektów zdrowotnych. Ważne wydaje się także wspieranie tej formy aktywności samorządów zarówno pod kątem merytorycznym, jak i finansowym. Agencja jest jedną $\mathrm{z}$ instytucji, która ma istotne znaczenie i ważną rolę 
do odegrania w zakresie wspomagania JST w opracowywaniu projektów PPZ o jak najwyższej jakości, co ma bezpośrednie przełożenie na ich efektywność, zaspokojenie potrzeb zdrowotnych oraz poprawę stanu zdrowia populacji.

\section{Aspekty prawne dotyczące projektowania i realizacji proglramów polityki zurowotnej w kontekście nowelizacii ustawy o świadczeniach opieki zdrowotnej finansowanych ze środków publicznych}

Kwestie dotyczące projektowania i realizacji PPZ są regulowane zapisami Ustawy z dnia 27 sierpnia 2004 roku o świadczeniach opieki zdrowotnej finansowanych ze środków publicznych (Dz.U. z 2019 roku poz. 1373 z późn. zm.), zwanej dalej ustawą o świadczeniach.

Zgodnie z zapisami ustawy o świadczeniach PPZ to „zespół zaplanowanych i zamierzonych działań z zakresu opieki zdrowotnej ocenianych jako skuteczne, bezpieczne i uzasadnione, umożliwiających osiągnięcie w określonym terminie założonych celów, polegających na wykrywaniu i zrealizowaniu określonych potrzeb zdrowotnych oraz poprawy stanu zdrowia określonej grupy świadczeniobiorców, opracowany, wdrażany, realizowany i finansowany przez ministra albo jednostkę samorządu terytorialnego".

PPZ dotyczą ważnych zjawisk epidemiologicznych, problemów zdrowotnych (innych niż epidemiologiczne) i kierowane są do całej lub określonej grupy docelowej chorych - przy istniejących możliwościach eliminowania bądź ograniczania tych problemów oraz wdrażania nowych procedur medycznych i profilaktyki. Mogą być realizowane w okresie jednego roku lub wieloletnim.

Nowelizacja Ustawy z dnia 27 sierpnia 2017 roku o świadczeniach opieki zdrowotnej finansowanych ze środków publicznych (Dz.U. z 2017 roku poz. 1938) wprowadziła kilka kluczowych zmian związanych z projektowaniem i realizacją PPZ.

Najbardziej istotną zmianą w obecnych przepisach jest wiążący charakter opinii prezesa agencji. Rozpoczęcie wdrożenia, realizacji i finansowania PPZ może nastąpić wyłącznie po uzyskaniu pozytywnej lub warunkowo pozytywnej opinii prezesa AOTMiT. Oznacza to, że projekty PPZ zaopiniowane negatywnie nie mogą być realizowane, natomiast projekty PPZ zaopiniowane pozytywnie warunkowo przed rozpoczęciem realizacji PPZ muszą zostać uzupełnione o uwagi zawarte w opinii prezesa agencji. Jednocześnie ustawa o świadczeniach nie nakłada na AOTMiT obowiązku weryfikacji, czy uwagi zostały do projektu PPZ poprawnie wdrożone.

Kolejna $\mathrm{z}$ ważniejszych zmian dotyczy projektów PPZ, które stanowią kontynuację w niezmienionej formie PPZ realizowanych w poprzednim okresie, dla których wydano pozytywną/pozytywną warunkową opinię lub rekomendację, o której mowa w art. 48aa ust. 5 lub 6 ustawy o świadczeniach. Zgodnie z zapisami ustawy wyżej wymienione projekty PPZ są zwolnione z obowiązku uzyskania opinii prezesa agencji, przy czym konieczne jest nadesłanie oświadczenia o zgodności projektu PPZ ze wskazaną rekomendacją.

Projekty PPZ przekazywane do oceny do agencji muszą zostać opracowane według wzoru określonego w Rozporządzeniu Ministra Zdrowia z dnia 22 grudnia 2017 roku w sprawie wzoru programu polityki zdrowotnej, wzoru raportu końcowego z realizacji PPZ oraz sposobu sporządzenia projektu PPZ i raportu końcowego z realizacji PPZ (Dz.U. z 2017 roku poz. 2476). W przypadku braku zgodności projektu ze wzorem agencja ma obowiązek wezwać podmiot do jego uzupełnienia. Okres wydania opinii prezesa agencji liczony jest od daty wpływu poprawionego projektu PPZ. Ustawa o świadczeniach nie określa jednak, w jakim czasie podmiot ma projekt poprawić.

Bardzo ważnym aspektem, który został wprowadzony wraz z nowelizacją ustawy o świadczeniach, jest konieczność nadsyłania do agencji raportów końcowych z realizacji PPZ. Wszystkie PPZ, których realizacja zakończy się, począwszy od dnia wejścia w życie ustawy pilotażowej, to jest 30 listopada 2017 roku, muszą zostać sprawozdane do agencji w terminie do trzech miesięcy od ich zakończenia. Za datę zakończenia realizacji PPZ uznaje się datę zamieszczoną $\mathrm{w}$ zaopiniowanym przez agencję programie. Ustawa o świadczeniach nie nakazuje przesyłania okresowych danych z realizacji PPZ.

Warto także zaznaczyć, że z przepisu art. 48a ust. 5 pkt 1 lit. a ustawy o świadczeniach wynika, że PPZ i PPZ będący jego kontynuacją stanowią dwa odrębne programy polityki zdrowotnej. Zatem zasadne jest przekazywanie do agencji raportów końcowych z realizacji obydwu PPZ. JST może również zawiesić realizację PPZ, ale na okres nie dłuższy niż dwa lata.

Nowelizacja ustawy nie zmienia definicji PPZ, obowiązku zasięgnięcia opinii agencji (z wyjątkiem wyżej wymienionych sytuacji), terminu wydania opinii przez agencję, zwolnienia z obowiązku opiniowania PPZ będących kontynuacjami (dotyczy opinii pozytywnych), możliwości współfinansowania PPZ przez NFZ (ale tylko w przypadku świadczeń gwarantowanych) oraz kryteriów, według których agencja wydaje opinię.

Obowiązujące przepisy prawne, w tym zmiany zapisów ustawy o świadczeniach, jak również uwagi przedstawione w opiniach prezesa agencji budzą wątpliwości interpretacyjne wśród JST i są przedmiotem zapytań kierowanych do agencji zarówno w zakresie projektowania, jak i realizacji PPZ. Agencja w ramach swoich możliwości i kompetencji udziela odpowiedzi na pytania i wyjaśnia wątpliwości w szczególności w zakresie uwag wskazywanych w opiniach prezesa. Należy jednak zaznaczyć, że AOTMiT nie jest właściwym organem $\mathrm{w}$ tym zakresie i nie posiada uprawnień do wydawania interpretacji przepisów prawa, zatem wszelkie wątpliwości co do zapisów omawianej ustawy należy kierować do odpowiednich organów władzy ustawodawczej. 


\section{Raporty instytucji nadzorujacych i kontrolujacych w zakresie realizacij programów polityki zurowotnej}

Raport Najwyższej Izby Kontroli na temat wyników kontroli w zakresie realizacji programów polityki zdrowotnej przez jednostki samorządu terytorialnego

W 2016 roku został opublikowany raport NIK pod tytułem „Informacja o wynikach kontroli w zakresie Realizacja programów polityki zdrowotnej przez jednostki samorządu terytorialnego", zwany dalej Raportem NIK. Celem głównym kontroli była ocena skuteczności realizacji przez JST zadań z zakresu ochrony i promocji zdrowia $w$ ramach programów polityki zdrowotnej i ich wpływu na poprawę zdrowia i jakości życia mieszkańców. Kontrolą objęto 26 JST realizujących $178 \mathrm{PPZ}$ w latach 2013-2015 (do czasu zakończenia kontroli) z uwzględnieniem okresów wcześniejszych, jeśli zdarzenia mające wówczas miejsce miały wpływ na kontrolowany okres. Badaniem i oceną objęto: stan przygotowania JST do realizacji zadań w zakresie ochrony zdrowia; opracowanie PPZ; wdrażanie i realizację PPZ; finansowanie PPZ; monitorowanie i ewaluację PPZ.

Zgodnie z wynikami kontroli NIK trudna sytuacja finansowa wielu JST (niedostatek dochodów, znaczny deficyt budżetowy) powoduje, że niewiele samorządów decyduje się na wydatkowanie środków finansowych na cele z zakresu ochrony i promocji zdrowia, co sprawia, że samorządowe PPZ mają niewielki udział w finansowaniu świadczeń. Udział wydatków JST sklasyfikowanych w rozdziale 85149 - Programy polityki zdrowotnej w wydatkach ogółem w latach 20102015 był znikomy i wynosił średnio 0,038\% (najniższy w 2013 roku - 0,033\%, najwyższy w 2010 roku-0,046\%). Również udział wydatków sklasyfikowanych w rozdziale $85149 \mathrm{w}$ wydatkach budżetowych na ochronę zdrowia (dział 851) był niewielki i wynosił średnio 1,83\% (najniższy w 2013 roku - 1,58\%, najwyższy w 2010 roku - 2,08\%). Zgodnie z wynikami przedstawionymi w Raporcie NIK jedynie co dziesiąta JST objęta badaniem w 2015 roku posiadała lokalną/ regionalną politykę zdrowotną, a co czwarty samorząd w 2015 roku realizował i finansował ze środków własnych PPZ. NIK zwróciła również uwagę na duże zróżnicowanie pod względem terytorialnym $\mathrm{w}$ dostępie Polaków do oferty zdrowotnej proponowanej przez poszczególne samorządy swoim mieszkańcom. Średnioroczne wydatki JST z lat 2010-2015 sklasyfikowane w rozdziale 85149 wynosiły średnio $1,6 \mathrm{zł} \mathrm{w}$ przeliczeniu na jednego mieszkańca. Różnice między bogatszymi, zurbanizowanymi województwami a regionami biedniejszymi są ponaddziesięciokrotne (od 0,3 zł w woj. warmińsko-mazurskim, $0,4 \mathrm{zł} \mathrm{w}$ woj. podlaskim, 0,6 zł w woj. lubuskim do $4,3 \mathrm{zł} \mathrm{w} \mathrm{woj.} \mathrm{mazo-}$ wieckim, 4,2 w woj. dolnośląskim). Powyższe znajduje także odzwierciedlenie w liczbie PPZ zaopiniowanych przez agencję. W latach 2010-2015 najmniej PPZ realizowano w województwach: warmińsko-mazurskim (19), lubuskim (22), podlaskim (24). Z kolei największą liczbę ocenianych PPZ odnotowano w województwach: śląskim (225, przy czym wydatki na jednego mieszkańca oscylowały na poziomie $1,2 \mathrm{zł}$ ), mazowieckim (184) i dolnośląskim (174).

Zgodnie z wynikami ogólnej oceny kontrolowanej działalności przez NIK realizacja przez JST zadań $\mathrm{z}$ zakresu ochrony i promocji zdrowia $\mathrm{w}$ ramach PPZ ze względu na ograniczony zakres i skalę tych działań nie przyczynia się $\mathrm{w}$ istotny sposób do poprawy zdrowia i jakości życia Polaków. Oprócz niewielkich nakładów finansowych istotne znaczenie mają uwarunkowania prawne i organizacyjne realizacji samorządowego programu polityki zdrowotnej, które obniżają skuteczność podejmowanych działań.

Do najistotniejszych wad systemowych, zidentyfikowanych w wyniku kontroli, należy zaliczyć różnice w dostępie do PPZ z uwagi na fakt, że ich liczba i zakres są uzależnione od statusu materialnego danej JST. W konsekwencji dostępność programu jest uwarunkowana miejscem zamieszkania i ograniczona dla mieszkańców gmin o niskich dochodach. Raport NIK zwraca również uwagę na brak precyzyjnych wskazówek, w jaki sposób program powinien być opracowany, wdrażany, realizowany i monitorowany, oraz niewskazanie w przepisach szczególnych podmiotu upoważnionego do jego uchwalenia (w przypadku gmin istnieje domniemanie, iż jest to organ stanowiący, samorządu województwa - organ wykonawczy, natomiast $\mathrm{w}$ odniesieniu do powiatu brak jest jednoznacznego domniemania kompetencji). Podkreślono także niewystarczającą koordynację realizacji programów przez władze publiczne, co skutkuje prowadzeniem takich samych działań na danym obszarze oraz brak mechanizmów weryfikacji danych w ramach procesu przekazywania stosownych informacji o realizowanych programach między szczeblami administracji samorządowej i rządowej.

Mimo wspomnianych uwarunkowań kontrolowane JST podejmowały inicjatywy prozdrowotne $\mathrm{w}$ zakresie ochrony zdrowia mieszkańców i były dobrze przygotowane organizacyjnie do działań w tym zakresie. Decydując się na opracowanie PPZ, brano na ogół pod uwagę istotność problemów epidemiologicznych, społeczne zapotrzebowanie na dane świadczenie oraz efektywność kosztową podejmowanych działań. Równocześnie jednak zdecydowana większość JST nie opracowała dokumentów strategicznych dotyczących planowanych działań w dłuższej perspektywie, opartych na analizie trendów demograficznych i epidemiologicznych, w celu lepszego zabezpieczenia potrzeb zdrowotnych mieszkańców.

W ocenie NIK punktem wyjścia do opracowywania i skutecznego wdrażania PPZ powinny być lokalne/regionalne strategie zdrowotne, uwzględniające między innymi dane $\mathrm{z}$ zakresu demografii, epidemiologii oraz informacje o zasobach systemu ochrony zdrowia wraz z analizą uwarunkowań społecznych.

Stwierdzone w toku kontroli formalne nieprawidłowości we wdrażaniu, realizacji, finansowaniu, monitorowaniu i ewaluacji PPZ nie miały istotnych skutków dla realizacji zadań w tym zakresie. 
W celu zwiększenia skuteczności realizacji przez JST PPZ, a w konsekwencji poprawy zdrowia i jakości życia mieszkańców, NIK w raporcie z kontroli wnosi o podjęcie przez ministra zdrowia działań mających na celu stworzenie przez ministra zdrowia we współpracy z NFZ, AOTMiT, środowiskiem eksperckim i samorządowym zbioru dobrych praktyk dotyczących samorządowych PPZ wraz z wzorcowymi programami, których tematyka powinna odnosić się do najistotniejszych zidentyfikowanych problemów zdrowotnych Polaków. Realizacja takich wzorcowych programów przez JST mogłaby się wiązać ze zwolnieniem tych podmiotów z obowiązku przekazywania projektów takich programów do zaopiniowania przez AOTMiT. Ponadto NIK w raporcie zwraca uwagę na zapewnienie stałego i adekwatnego do potrzeb źródła finansowania samorządowych PPZ; poprawę koordynacji działań podejmowanych w ramach programów między JST a administracją rządową i NFZ, a także stworzenie mechanizmów weryfikacji danych w ramach procesu przekazywanych informacji o realizowanych programach. Według NIK powyższe rozwiązania powinny zostać uwzględnione w procesie legislacyjnym mającym na celu dokonanie zmian w obowiązujących przepisach dotyczących PPZ (art. 48-48b ustawy o świadczeniach), tak aby: zawierały upoważnienie ustawowe dla ministra właściwego do spraw zdrowia do określenia w formie rozporządzenia wzorcowych PPZ wraz z wytycznymi co do treści tych programów.

Ponadto w Raporcie NIK wskazano na konieczność zwiększenia liczby i zakresu ogólnopolskich programów profilaktycznych realizowanych przez ministra zdrowia, które powinny wynikać z rozpoznanych potrzeb zdrowotnych oraz stanu zdrowia Polaków, a także odnosić się do najistotniejszych problemów i zagrożeń zdrowotnych.

Odnosząc aktualny stan prawny do Raportu NIK z 2016 roku, warto zaznaczyć, że część z zaproponowanych rozwiązań znalazła odzwierciedlenie w nowelizacji ustawy o świadczeniach z 2017 roku, między innymi kwestia określenia $\mathrm{w}$ formie rozporządzenia wzorcowych PPZ oraz wytycznych co do treści tych programów.

Raport Ministerstwa Zdrowia o zrealizowanych lub podjetych zadaniach z zakresu zdrowia publicznego w latach 2016 i 2017

W 2018 roku Ministerstwo Zdrowia (MZ) opublikowało raport pod tytułem „Informacja o zrealizowanych lub podjętych zadaniach z zakresu zdrowia publicznego w roku 2016 i 2017", zwany dalej Raportem MZ. Zgodnie z treścią Raportu MZ dokument został przygotowany na podstawie Ustawy z dnia 11 września 2015 roku o zdrowiu publicznym (Dz.U. z 2018 roku poz. 1492) i stanowi pierwsze sprawozdanie na temat aktywności administracji publicznej i jednostek z nią współpracujących w ramach wyżej wymienionej ustawy oraz Rozporządzenia Rady Ministrów z dnia 4 sierpnia 2016 roku w sprawie Narodowego Programu Zdrowia na lata 2016-2020, zwanego dalej NPZ, stanowiącego podstawowy akt wykonawczy wydawany na podstawie wyżej wymienionej ustawy. Informacje zawarte w sprawozdaniu zostały oparte na danych zgromadzonych od podmiotów włączonych w realizację zadań z zakresu zdrowia publicznego, które zostały określone w art. 3 wyżej wymienionej ustawy. Sprawozdanie podzielono na cztery części - w pierwszej wskazano struktury odpowiedzialne za realizację zadań z zakresu zdrowia publicznego, w drugiej procesy - działania zrealizowane lub podjęte w okresie objętym sprawozdaniem, w trzeciej - rezultaty działań w kontekście sytuacji zdrowotnej ludności Rzeczypospolitej Polskiej, a w czwartej - wnioski i zalecenia wynikające z analizy podjętych i realizowanych zadań z zakresu zdrowia publicznego.

W treści sprawozdania przedstawiono informację na temat PPZ realizowanych przez MZ o zasięgu ogólnopolskim. Ponadto przedstawiono także dane dotyczące zadań z zakresu zdrowia publicznego realizowanych przez NFZ, obejmujących między innymi realizację programów zdrowotnych oraz dofinasowanie programów polityki zdrowotnej realizowanych przez JST.

W odniesieniu do PPZ realizowanych przez JST w Raporcie MZ wskazano, iż zakres problemów zdrowotnych będących przedmiotem PPZ wpisuje się w cele operacyjne NPZ na lata 2016-2020. Zgodnie $\mathrm{z}$ danymi wskazanymi $\mathrm{w}$ Raporcie MZ najwięcej PPZ JST realizowały w ramach drugiego celu operacyjnego, czyli profilaktyki i rozwiązywania problemów związanych z używaniem substancji psychoaktywnych, uzależnieniami behawioralnymi i innymi zachowaniami ryzykownymi. W 2016 roku liczba zadań w ramach drugiego celu operacyjnego wynosiła 10,7 tys. (stanowiło to około 46\% ogółu), w 2017 roku liczba ta spadła do 10,4 tys., ale w związku z mniejszą liczbą sprawozdanych w tym roku zadań stanowiło to około $49 \%$. JST koncentrowały się również na pierwszym celu operacyjnym - poprawie sposobu żywienia, stanu odżywienia oraz aktywności fizycznej społeczeństwa. W 2016 roku informację o realizacji tego rodzaju zadań wykazało 6,1 tys. (26\%), a w 2017 roku - 5,0 tys. (24\%). JST w mniejszym zakresie realizowały zadania w ramach celu czwartego, czyli ograniczania ryzyka zdrowotnego wynikającego z zagrożeń fizycznych, chemicznych i biologicznych w środowisku zewnętrznym, miejscu pracy, zamieszkania, rekreacji oraz nauki, to jest 1,6 tys. zadań (około 7\%) w 2016 roku oraz 1,5 tys. w 2017 roku (również około 7\% ogółu). W niewielkim stopniu JST realizowały zadania w ramach pozostałych celów operacyjnych NPZ, czyli: profilaktyki problemów zdrowia psychicznego i poprawy dobrostanu psychicznego społeczeństwa; promocji zdrowego i aktywnego starzenia się oraz poprawy zdrowia prokreacyjnego. Zadania te stanowiły od 1 do 6\% ogółu sprawozdanych zadań. Część zadań z zakresu zdrowia publicznego sprawozdanych przez JST nie była związana z celami operacyjnymi NPZ, w 2016 roku zadań tych było 2,3 tys. (stanowiło to około 10\% ogółu), rok później tych zadań było mniej - 1,4 tys. (około 7\%). 
W Raporcie MZ podkreślono także, że realizowane PPZ wpisują się w priorytety zdrowotne, określane w formie Rozporządzenia Ministra Zdrowia w sprawie priorytetów zdrowotnych, na podstawie art. 31a ust. 2 Ustawy z dnia 27 sierpnia 2004 roku o świadczeniach opieki zdrowotnej finansowanych ze środków publicznych.

W Raporcie MZ przedstawiono między innymi informację o wysokości dofinansowania przez NFZ PPZ realizowanych przez JST. W 2017 roku NFZ dofinansował 112 programów polityki zdrowotnej, co stanowi około połowy projektów PPZ ocenianych przez agencję średnio w skali roku. Otrzymanie dofinansowania wymaga uzyskania pozytywnej opinii prezesa Agencji Oceny Technologii Medycznych i Taryfikacji oraz pozytywnej opinii wojewody. Wartość dofinansowania NFZ wynosiła 2831 tys. zł. i stanowiła ogółem 37\% łącznych środków przeznaczonych na realizację tych programów (pozostałe 63\% z kwoty 7704050 zł stanowiły środki JST). Spośród 112 programów 72 dotyczyły szczepień, w tym przeciwko grypie (22), HPV (31), meningokokom (6), pneumokokom (11), ospie wietrznej (2). Szczepienia przeciwko grypie przeznaczone były przede wszystkim dla osób starszych, po 60. roku życia. Istotną część programów stanowiły te dotyczące promowania zdrowego żywienia i aktywności fizycznej (15 programów), a także próchnicy (6 programów). 19 PPZ dotyczyło różnorodnej tematyki, w tym badań przesiewowych słuchu i wzroku, terapii dzieci niepełnosprawnych, profilaktyki i wczesnego wykrywania raka piersi, szyjki macicy, jelita grubego, profilaktyki następstw dysplazji stawów, edukacji z zakresu pierwszej pomocy.

Jak wskazano w Raporcie MZ, zapisy ustawy o zdrowiu publicznym wprowadziły nowy mechanizm współpracy merytorycznej między działaniami administracji samorządowej a wojewodą. Polega ona przede wszystkim na corocznym gromadzeniu i ocenie sprawozdań z realizacji zadań z zakresu zdrowia publicznego. W opinii autorów Raportu MZ wydaje się, że w dłuższej perspektywie współpraca ta powinna się przyczynić do lepszej koordynacji działań na poziomie regionalnym i lokalnym.

W Raporcie MZ stwierdzono, że poprawa sytuacji zdrowotnej społeczeństwa nie jest możliwa wyłącznie dzięki działaniom ministerstw czy struktur wykonawczych administracji rządowej. Podstawą pracy na rzecz zdrowia populacyjnego nie są (i nie powinny być - zgodnie z aktualnym stanem wiedzy naukowej) działania polegające na usprawnieniu organizacji systemu opieki zdrowotnej i podniesieniu poziomu jego finansowania. Udoskonalanie systemu opieki zdrowotnej jest bardzo istotnym elementem polityki zdrowotnej rządu, lecz w perspektywie zdrowia publicznego najważniejsze jest ukierunkowanie działań na promowanie zdrowia przez odpowiednią politykę lokalną, regionalną i centralną oraz tworzenie środowisk umożliwiających zachowanie i poprawę zdrowia - w miejscu pracy, zamieszkania, nauki czy rekreacji. Działania te, wspierane przez odpowiednio zorganizowaną profilaktykę kierowaną do ogółu społeczeństwa czy osób ze zwiększonym ryzykiem wystąpienia danego problemu zdrowotnego lub z już zdiagnozowaną jednostką chorobową, są niezbędne do poprawy zdrowia w ujęciu całego społeczeństwa, a nie pojedynczych obywateli. Znaczący odsetek JST (gmin, powiatów oraz województw) sprawozdał co najmniej jedno zadanie $\mathrm{z}$ zakresu zdrowia publicznego - łącznie w badanym przez MZ okresie udział ten wyniósł $87 \%$.

\section{Projektowanie, wdrazanie i realizacja PPZ z punktu widzenia JST}

W przypadku JST przepisy dotyczące realizowania zadań z zakresu zdrowia publicznego, w tym PPZ, reguluje oprócz Ustawy z dnia 27 sierpnia 2004 roku o świadczeniach opieki zdrowotnej finansowanych ze środków publicznych (dalej: ustawa o świadczeniach) (Dz.U. z 2019 roku poz. 1373 z późn. zm.) między innymi Ustawa z dnia 8 marca 1990 roku o samorządzie gminnym (Dz.U. z 2019 roku poz. 506).

Aktualne akty prawne nakładają na JST obowiązki i zadania z zakresu promocji i ochrony zdrowia. Zgodnie z zapisami ustawy o samorządzie gminnym jednym $\mathrm{z}$ zadań własnych gminy/powiatu/województwa w zakresie zapewnienia równego dostępu do świadczeń opieki zdrowotnej jest opracowanie i realizacja oraz ocena skutków PPZ wynikających z rozpoznanych potrzeb zdrowotnych i stanu zdrowia mieszkańców.

Zgodnie z zapisami ustawy o świadczeniach (art. 9a i 9b) JST w celu zaspokajania potrzeb wspólnoty samorządowej w zakresie ochrony zdrowia (uwzględniając W szczególności regionalną mapę potrzeb zdrowotnych, priorytety regionalnej polityki zdrowotnej oraz stan dostępności świadczeń opieki zdrowotnej na obszarze województwa) mogą finansować dla mieszkańców tej wspólnoty świadczenia gwarantowane. Biorąc pod uwagę powyższy zapis ustawy o świadczeniach, nie ma konieczności przygotowywania w tym zakresie programu polityki zdrowotnej.

Warto podkreślić, że samorządy również dokonują samodzielnej analizy realizowanych PPZ. Związek Powiatów Polskich w 2016 roku przedstawił publikację na temat PPZ (zwaną dalej Raportem ZPP) będących przedmiotem oceny agencji w latach 2010-2015 pod kątem określenia wskazówek dotyczących poprawnego opracowywania programów zdrowotnych, na przykładzie uwag przedstawionych w opiniach agencji [1].

W Raporcie ZPP wskazano na zróżnicowanie zakresu PPZ pod kątem liczby programów realizowanych przez poszczególne rodzaje JST (gminy, powiaty, województwa), również w odniesieniu do zróżnicowania terytorialnego. Przedmiotem analizy były także obszary, w których samorządy najczęściej podejmują działania profilaktyki zdrowotnej w odniesieniu do grup PPZ pod kątem problemów zdrowotnych (choroby zakaźne, choroby układu krążenia, choroby nowotworowe).

Autorzy Raportu ZPP, analizując i próbując badać skuteczność poszczególnych JST w uzyskaniu pozytywnej opinii agencji w latach 2014 i 2015, wnioskują, 
że na porównywalnych poziomach są gminy i miasta na prawach powiatu (w 2014 i 2015 roku odsetek opinii pozytywnych wynosił dla nich ponad $70 \%$ ). Natomiast w przypadku samorządów powiatowych i wojewódzkich odsetek opinii pozytywnych był niższy (około 50\% w 2014 i około 60\% w 2015 roku). Jako przyczynę wskazano większe skomplikowanie PPZ zgłaszanych przez powiaty i województwa. Większe jednostki to także większy teren oddziaływania i charakter programów (programy te dotyczą nie tylko działań o promocyjnych i powszechnie stosowanych, lecz także obejmują specjalistyczną profilaktykę). Samorządy wskazują na potrzebę udzielania szerokiego i różnorakiego wsparcia dla osób przygotowujących PPZ na poszczególnych szczeblach oraz konieczność spełniania określonych przepisami wymogów w tym zakresie.

\section{Monitorowanie i ewaluacja PPZ w Polsce}

Kwestia, która stanowi aktualnie istotny przedmiot dyskusji ekspertów z zakresu zdrowia publicznego, dotyczy ewaluacji PPZ. Na ten aspekt związany z projektowaniem i realizacją PPZ zwraca się uwagę w trakcie debat publicznych, paneli dyskusyjnych i spotkań ekspertów poświęconych polityce zdrowotnej w Polsce, szczególnie podkreślając w tym względzie rolę samorządów terytorialnych. Eksperci wskazują na znaczenie projektowania PPZ, które zapewnią wdrożenie i prowadzenie efektywnych działań przynoszących trwałe efekty zdrowotne w populacji.

Monitowanie i ewaluacja PPZ stanowią jeden z elementów projektu, który jest poddawany ocenie AOTMiT. Mając na uwadze zmiany ustawowe dotyczące konieczności sporządzania raportu końcowego z realizacji PPZ, w opiniach prezesa AOTMiT zwraca się uwagę na to, że wyniki monitorowania i ewaluacji będą stanowić istotną część raportu końcowego z realizacji PPZ. Monitorowanie jest procesem zbierania danych o realizacji programu i służy kontrolowaniu ich przebiegu i postępu. Ewaluacja natomiast jest analizą danych $\mathrm{z}$ PPZ realizowaną $\mathrm{w}$ celu oceny rezultatów prowadzonych działań. Wyniki monitorowania i ewaluacji umożliwiają bieżącą ocenę jego przebiegu oraz określenie wpływu programu na sytuację społeczną i zdrowotną w perspektywie wieloletniej.

Ewaluacja PPZ w Polsce w odniesieniu do międzynarodowych rozwiązań została opisana w publikacji Alicji Domagały, Katarzyny Dubas-Jakóbczyk i Romana Topór-Mądrego [3]. Celem artykułu jest prezentacja przykładów doświadczeń międzynarodowych i czynników warunkujących skuteczną ewaluację programów zdrowotnych oraz podjęcie próby nakreślenia rekomendacji dotyczących ewaluacji programów zdrowotnych w polskich warunkach systemowych.

Autorzy publikacji [3] wskazują, że planowanie ewaluacji jest integralną częścią procesu planowania każdego projektu. Ponadto stwierdzają, że ewaluacja działań jest standardem współczesnego zarządzania w sektorze publicznym, a podstawowe cele wdrażania ewaluacji to: dbałość o jakość realizowanych przedsięwzięć, spójność działań i ich skuteczność. Zatem istotność procesu ewaluacji odnosi się również do programów zdrowotnych.

Autorzy, powołując się na definicję Centers for Disease Control and Prevention (CDC), zaznaczają także, że skuteczna ewaluacja programu zdrowotnego to systematyczna analiza wdrażania oraz wyników strategii i interwencji z zamiarem wykorzystania wniosków w celu poprawy tychże działań. Wskazując na wzorce zaleceń dotyczących procesu ewaluacji, odnoszą się do najbardziej znanej i najczęściej przywoływanej matrycy ewaluacji Framework of Program Evaluation in Public Health, opracowanej przez US CDC.

W publikacji [3] wskazano także inne przykłady rozwiązań międzynarodowych w zakresie formalnego wspierania procesu planowania, realizacji oraz ewaluacji programów zdrowotnych. Zadania te pełnią w poszczególnych krajach wyznaczone w tym celu instytucje: w Wielkiej Brytanii National Institute for Health and Care Excellence (NICE), w Stanach Zjednoczonych The US Preventive Services Task Force oraz The Community Preventive Services Task Force, w Kanadzie Canadian Best Practices Portal for Health Promotion and Chronic Disease Prevention. Instytucje te dostarczają wytycznych, zaleceń oraz praktycznych narzędzi mających na celu wsparcie podmiotów realizujących programy zdrowotne (między innymi zalecenia dotyczące planowania, implementacji, schemat ewaluacji, kryteria audytu, wytyczne dotyczące efektywności kosztowej, katalog najlepszych praktyk).

Według autorów [3] w Polsce brakuje wystandaryzowanych zaleceń i wytycznych, które byłyby narzędziem ułatwiającym poszczególne kroki procesu planowania, wdrażania i ewaluacji programu zdrowotnego. W artykule podkreślono, że AOTMiT udostępnia schemat oraz zalecenia dotyczące konstrukcji programu zdrowotnego jako element wsparcia realizacji samorządowych programów zdrowotnych. W opinii autorów publikacji schemat ten tylko w sposób hasłowy odnosi się w kilku punktach do uwzględnienia elementu ewaluacji $\mathrm{w}$ procesie planowania programu. Autorzy, powołując się na wyniki badań empirycznych projektów programów zdrowotnych przedkładanych do AOTMiT przez JST, wskazują, że ponad połowa $\mathrm{z}$ nich $\mathrm{w}$ ogóle nie uwzględnia elementu ewaluacji, a wśród tych, które ten element biorą pod uwagę, zastosowane wskaźniki pomiaru w większości przypadków nie są właściwie dobrane. Należy przy tym podkreślić, iż zgodnie z cytowanym materiałem źródłowym [2] wspomniane w publikacji badania empiryczne dotyczyły projektów PPZ nadesłanych do AOTMiT w 2012 roku, a zatem w początkowym okresie opiniowania PPZ. Próbę badawczą stanowiło 209 losowo wybranych z 331 udostępnionych przez AOTMiT projektów PPZ (63\%).

Z kolei w publikacji Domagały i Dubas-Jakóbczyk [4] zwrócono wagę na poprawę jakości programów zdrowotnych opracowywanych przez samorządy, dokumentując to rosnącym trendem w wydawaniu przez AOTMiT pozytywnych/pozytywnych warunkowych opinii - 72\% w 2014 roku w porównaniu z 59\% w 2012 roku. Autorki [4], powołując się na przykłady innych 
krajów, wskazują, iż realizacja samorządowych programów zdrowotnych może stanowić skuteczne narzędzie poprawy stanu zdrowia populacji. Jednakże, zdaniem autorek, w celu maksymalizowania korzyści płynących $\mathrm{z}$ angażowania struktur lokalnych $\mathrm{w}$ działania $\mathrm{z}$ zakresu promocji zdrowia i prewencji chorób niezbędne jest zapewnienie odpowiedniego systemu wsparcia. W publikacji rekomendowano, by system wsparcia obejmował trzy wzajemnie powiązane i zintegrowane elementy: portal danych epidemiologicznych, zestaw interaktywnych narzędzi wspomagających oraz projekty z zakresu kształcenia ustawicznego.

Ponadto, jak wspomniano w publikacji [3], proces przeprowadzenia działań ewaluacyjnych wymaga zaangażowania odpowiednich zasobów. Autorzy powołują się na rekomendację Światowej Organizacji Zdrowia (World Health Organization, WHO), według której około $10 \%$ budżetu programu promocji zdrowia powinno być przeznaczone na ewaluację prowadzonych działań. Autorzy konkludują, iż powyższy fakt pokazuje, jak duże znaczenie ma etap realizacji programu dotyczący ewaluacji dla sukcesu całokształtu działań.

Mając na uwadze powyższe, warto zaznaczyć, że agencja podejmuje działania $\mathrm{z}$ zakresu tworzenia wzorcowych narzędzi i budowy systemu wsparcia dla JST. Należy wspomnieć o inicjatywach aktualnie realizowanych przez AOTMiT w tym zakresie. Należy do nich repozytorium PPZ, które AOTMiT udostępnia w Biuletynie Informacji Publicznej oraz na swojej stronie internetowej.

Agencja jest jedną z kilku instytucji współpracujących w ramach projektu ProfiBaza - Cyfrowe udostępnienie informacji publicznej na temat sytuacji zdrowotnej ludności oraz realizacji programów zdrowotnych na potrzeby profilaktyki chorób i promocji zdrowia w Polsce. Realizatorem projektu jest Narodowy Instytut Zdrowia Publicznego - Państwowy Zakład Higieny (NIZP-PZH). Zgodnie z założeniami projektu ProfiBaza ma zostać stworzony zbiór danych, który pokaże, jakie działania z zakresu zdrowia publicznego są podejmowane w Polsce, czy odpowiadają one potrzebom zdrowotnym społeczności lokalnych, ile kosztują i jakie są ich rezultaty. Ponadto udostępnienie systemu informacji na temat zdrowia ma umożliwić podejmowanie racjonalnych i opartych na dowodach decyzji, wzmocnić krajowy system zdrowotny oraz pozwolić na lepsze gospodarowanie publicznymi środkami finansowymi, będącymi w dyspozycji administracji rządowej i samorządowej.

Warto także podkreślić, że agencja w ramach Programu Operacyjnego Wiedza Edukacja Rozwój (POWER) samodzielnie realizuje projekt pod nazwą „Racjonalne decyzje w systemie ochrony zdrowia, ze szczególnym uwzględnieniem regionalnej polityki zdrowotnej”, który wpisuje się w koncepcje tworzenia odpowiednich systemów wsparcia i udostępniania narzędzi dla JST. Głównym celem projektu jest bowiem poprawa efektywności systemu ochrony zdrowia między innymi w zakresie tworzenia samorządowych PPZ oraz regionalnych strategii ochrony zdrowia. W ramach działań zaplanowano też bezpłatne szkolenia w zakresie tworzenia PPZ, które mają na celu podnoszenie umiejętności i świadomości w JST, a zdobyta wiedza ma się przełożyć na podejmowanie racjonalnych decyzji na najniższych szczeblach samorządu terytorialnego.

\section{Aspekty związane z oceną PPZ z punktu widzenia agencji}

\section{Analiza danych dotyczących liczby i rodzaju projektów PPZ ocenianych przez agencje w latach 2010-2019}

Obowiązek opiniowania PPZ przez AOTMiT został wprowadzony w 2009 roku. Pierwsze opinie prezesa agencji w sprawie PPZ zostały wydane w 2010 roku. W okresie 2010-sierpień 2019 wydano łącznie 2277 opinii prezesa agencji w sprawie projektów PPZ. W Tabeli I przedstawiono szczegółowe zestawienie liczby opinii wydanych w poszczególnych latach, z uwzględnieniem wyniku oceny.

Trend w zakresie liczby opinii wydanych w poszczególnych latach przestawia Rysunek 1.

W analizowanym okresie średnia liczba opinii wydawanych w ciągu jednego roku wynosi około 230. Najwięcej opinii w skali roku zostało wydanych w 2017 roku (351). Wyznaczona liniowa funkcja trendu wskazuje na powolny, rosnący w czasie trend liczby opinii wydawanych w skali roku, przy czym należy podkreślić, że czasowe punkty krańcowe (2010 i 2019 rok) nie obejmują pełnych lat.

Na Rysunkach 2 i 3 przedstawiono odpowiednio liczbę opinii w zależności od wyniku oceny oraz odsetek opinii negatywnych wydanych kolejno w latach 2010-sierpień 2019.

W analizowanym okresie odsetek opinii negatywnych wydawanych w ciągu jednego roku wynosi średnio $30 \%$. Najniższy odsetek opinii negatywnych uzyskano w 2018 roku $(15 \%, 36 / 239$ opinii), a najwyższy w 2012 roku (42\%, 113/272 opinie). Wyznaczona liniowa funkcja trendu wskazuje na powolny, malejący w czasie trend liczby opinii negatywnych wydawanych w skali roku, przy czym należy podkreślić, że czasowe punkty krańcowe (2010 i 2019 rok) nie obejmują pełnych lat.

Odnosząc się do dziedziny medycyny lub problemu zdrowotnego, których dotyczą przesyłane do agencji projekty PPZ, można wnioskować, że najczęściej mają one związek z profilaktyką $\mathrm{w}$ formie szczepień przeciwko wirusowi brodawczaka ludzkiego, grypie, pneumokokom i meningokokom (łącznie 32\% projektów PPZ). Projekty PPZ z zakresu onkologii stanowią około $10 \%$ projektów przekazywanych do zaopiniowania agencji, przy czym najwięcej z ich odnosi się do wykrywania i profilaktyki raka piersi i gruczołu krokowego. Projekty PPZ często dotyczą także interwencji z zakresu rehabilitacji i stomatologii, odpowiednio 6\% i 5\% projektów PPZ wpływających do oceny agencji. Pozostałe dziedziny medycyny będące często przedmiotem PPZ to kardiologia, dietetyka i diabetologia, a także ortopedia (wykrywanie i profilaktyka wad postawy) oraz zdrowie psychiczne i promocja zdrowia. 


\begin{tabular}{|l|c|c|c|c|c|}
\hline $\begin{array}{c}\text { Rok wydania } \\
\text { opinii }\end{array}$ & $\begin{array}{c}\text { Liczba opinii } \\
\text { ogólem }\end{array}$ & $\begin{array}{c}\text { Liczba opinii pozytywnych/ } \\
\text { pozytywnych warunkowych }\end{array}$ & $\begin{array}{c}\text { Liczba opinii } \\
\text { negatywnych }\end{array}$ & $\begin{array}{c}\text { Odsetek opinii } \\
\text { pozytywnych/pozytywnych } \\
\text { warunkowych }\end{array}$ & $\begin{array}{c}\text { Odsetek opinii } \\
\text { negatywnych }\end{array}$ \\
\hline 2010 & 67 & 46 & 20 & $69 \%$ & $30 \%$ \\
\hline 2011 & 187 & 116 & 70 & $62 \%$ & $37 \%$ \\
\hline 2012 & 272 & 159 & 113 & $58 \%$ & $42 \%$ \\
\hline 2013 & 294 & 193 & 101 & $66 \%$ & $34 \%$ \\
\hline 2014 & 288 & 206 & 52 & $72 \%$ & $28 \%$ \\
\hline 2015 & 212 & 155 & 81 & $73 \%$ & $27 \%$ \\
\hline 2016 & 240 & 251 & 100 & $76 \%$ & $34 \%$ \\
\hline 2017 & 239 & 203 & 36 & $85 \%$ & $28 \%$ \\
\hline 2018 & 127 & 97 & 30 & $76 \%$ & $15 \%$ \\
\hline 2019 & $\mathbf{1 5 8 5}$ & $\mathbf{6 9 0}$ & $\mathbf{7 0 \%}$ & $24 \%$ \\
\hline Suma & & & & $\mathbf{3 0 \%}$ \\
\hline
\end{tabular}

Tabela I. Zestawienie liczby opinii prezesa agencji w sprawie PPZ wydanych w okresie 2010-sierpień 2019 Źródło: Opracowanie własne.

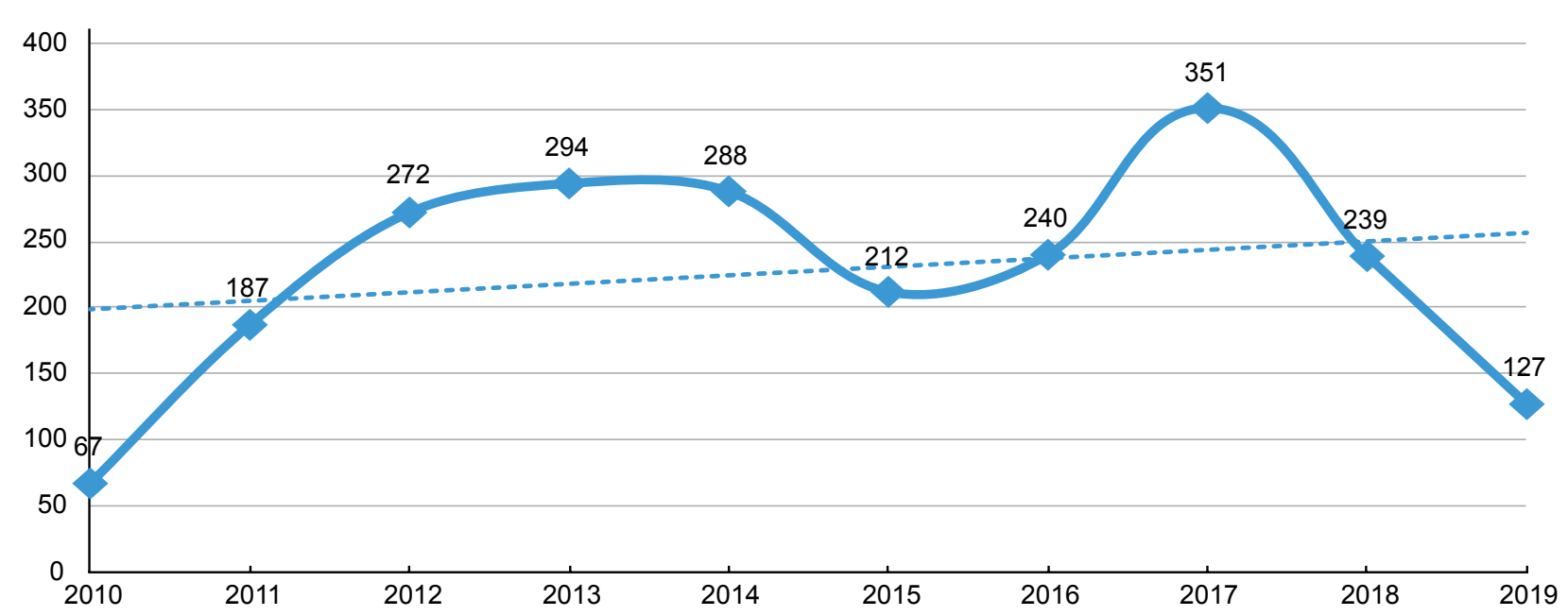

Rysunek 1. Liczba opinii o projektach PPZ wydanych w poszczególnych latach w okresie 2010-sierpień 2019 Źródło: Opracowanie własne.

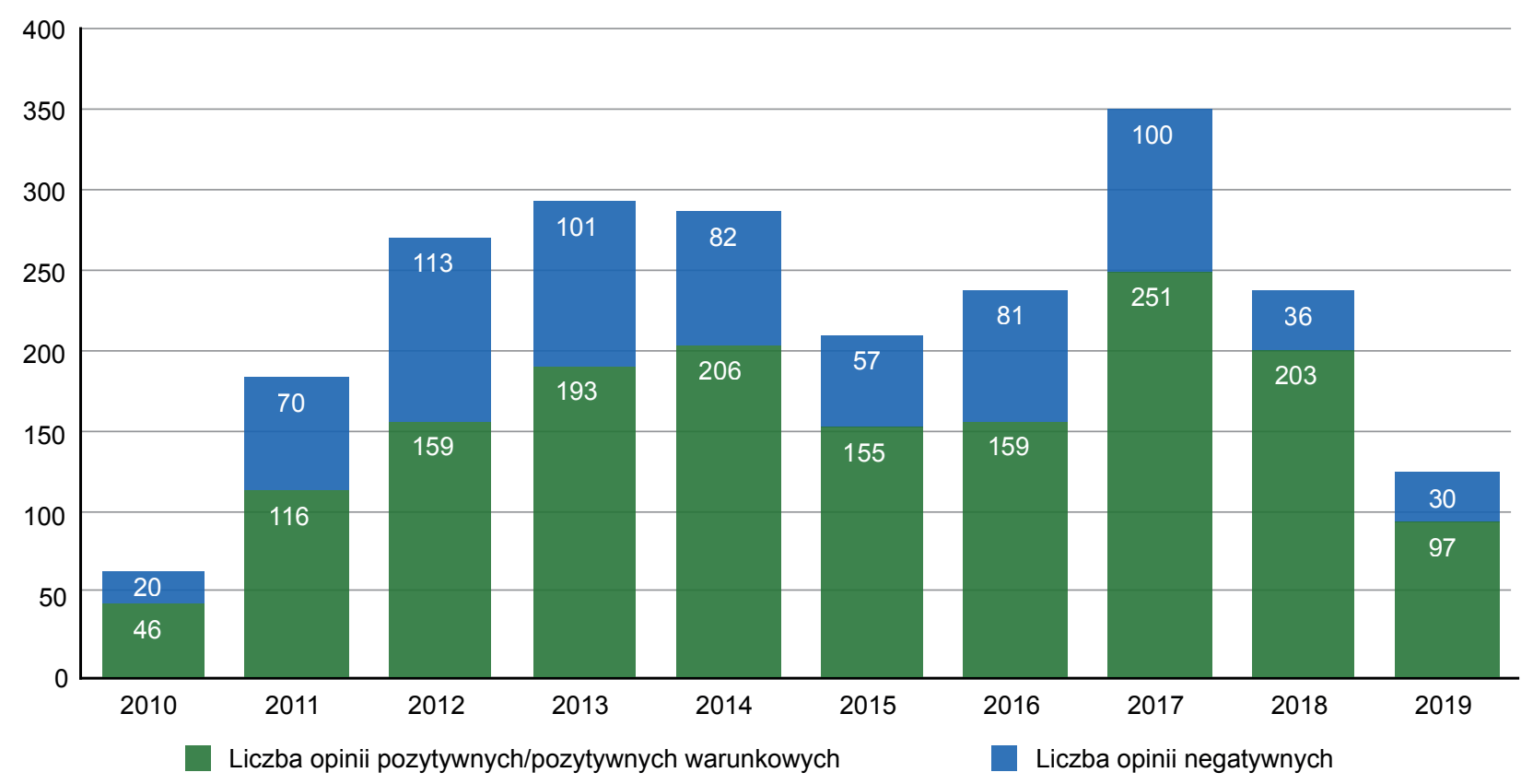

Rysunek 2. Liczba opinii wydanych w kolejnych latach w okresie 2010-sierpień 2019 w zależności od wyniku oceny Źródto: Opracowanie własne. 


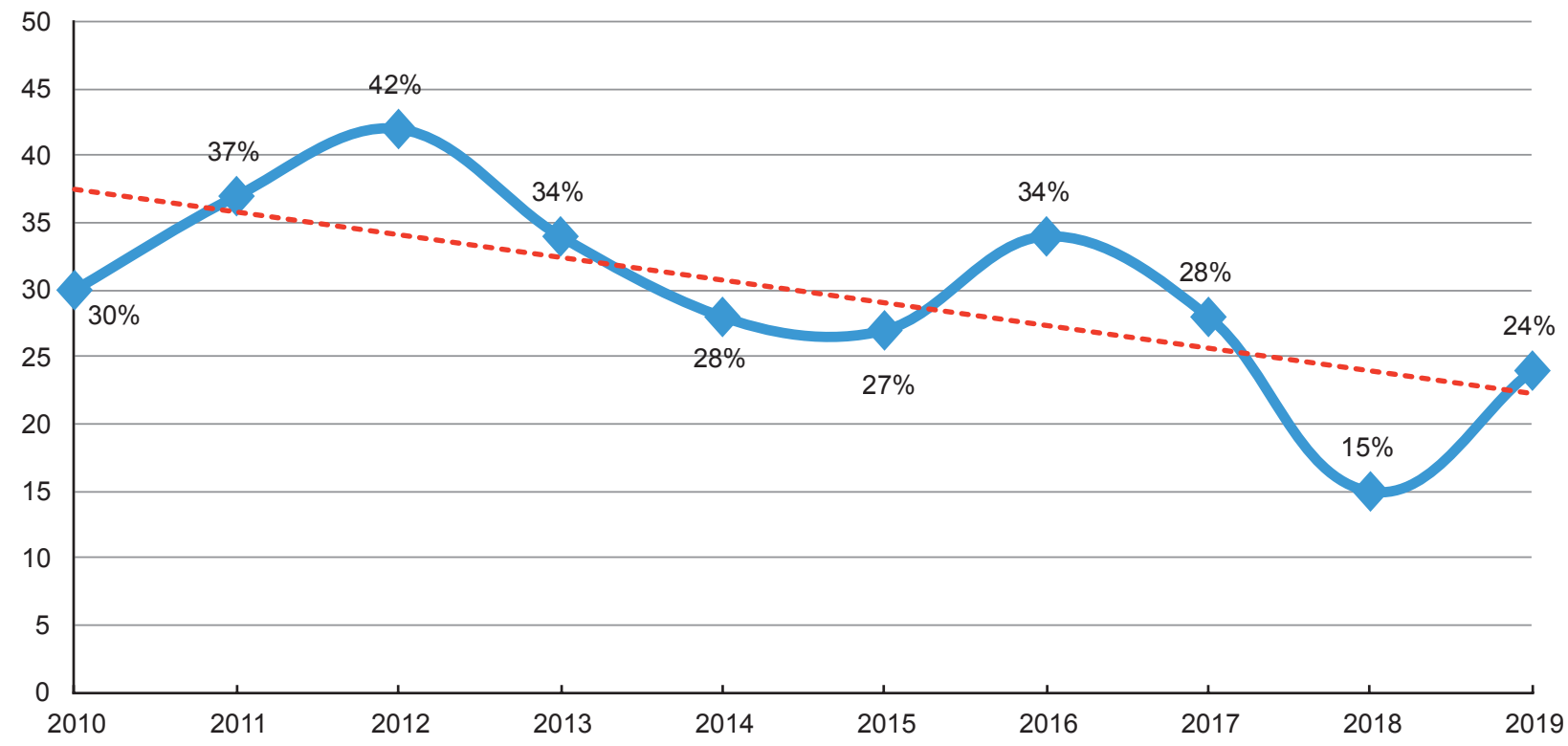

Rysunek 3. Odsetek opinii negatywnych wydanych w kolejnych latach w okresie 2010-sierpień 2019

Źródto: Opracowanie własne.

W Tabeli II przedstawiono odsetek projektów PPZ przekazywanych do zaopiniowania przez agencję w odniesieniu do najczęściej wybieranej dziedziny medycyny/problemu zdrowotnego.

Analiza projektów PPZ nadsyłanych do agencji pod względem szczebla samorządu terytorialnego wskazuje, że najwięcej projektów PPZ przekazują do agencji JST na szczeblu gminnym (około $76 \%$ ), około $12 \%$ projektów pochodzi z powiatów, a około $9 \%$ nadsyłanych jest przez województwa. W ogólnej liczbie projektów PPZ

\begin{tabular}{|l|c|}
\hline $\begin{array}{c}\text { Dziedzina medycyny/problem } \\
\text { zdrowotny }\end{array}$ & $\begin{array}{c}\text { Odsetek PPZ wplywających } \\
\text { do oceny przez AOTMiT }\end{array}$ \\
\hline szczepienia - HPV & $14 \%$ \\
\hline szczepienia - grypa & $12 \%$ \\
\hline szczepienia - pneumokoki & $6 \%$ \\
\hline rehabilitacja & $6 \%$ \\
\hline stomatologia & $5 \%$ \\
\hline onkologia - rak piersi & $3 \%$ \\
\hline zdrowie psychiczne & $3 \%$ \\
\hline dietetyka & $3 \%$ \\
\hline onkologia - gruczoł krokowy & $3 \%$ \\
\hline kardiologia & $3 \%$ \\
\hline szczepienia - meningokoki & $2 \%$ \\
\hline ortopedia - wady postawy & $2 \%$ \\
\hline promocja zdrowia & $2 \%$ \\
\hline diabetologia & $2 \%$ \\
\hline
\end{tabular}

Tabela II. Dziedziny medycyny/problemy zdrowotne, których najcześciej dotycza projekty PPZ przekazywane do zaopiniowania agencji

Źródło: Opracowanie własne. około $2 \%$ stanowią programy przygotowane przez ministra zdrowia. Warto także zwrócić uwagę na zróżnicowanie terytorialne w zakresie liczby projektów PPZ przekazywanych do oceny agencji z poszczególnych województw, co może się przekładać na nierówności w dostępie do świadczeń zdrowotnych. Najwięcej projektów zostało przekazanych do zaopiniowania z województw: śląskiego (16\%), mazowieckiego (14\%) i dolnośląskiego (12\%), najmniej zaś z województw: warmińsko-mazurskiego (3\%), lubuskiego (3\%) i podlaskiego (2\%).

\section{Analiza problemów związanych z projektowaniem, oceną i wdrażaniem PPZ z punktu widzenia AOTMiT}

Problemy związane z realizacją PPZ są przedmiotem zapytań kierowanych przez JST bezpośrednio do agencji. JST przed rozpoczęciem lub w trakcie realizacji programów często zmagają się z trudnościami związanymi $\mathrm{z}$ interpretacją przepisów prawa oraz uwag zawartych w opiniach prezesa AOTMiT. JST mają także wątpliwości, czy podczas realizacji programu mogą wprowadzić zmiany bez konieczności ponownej oceny agencji. Najczęściej zgłaszane problemy i wątpliwości dotyczą zmian w zakresie populacji docelowej, planowanych interwencji, budżetu czy warunków realizacji. Zapytania JST dotyczące niejasności związanych $\mathrm{z}$ interpretacją przepisów prawa lub uwag zawartych w opinii kierowane są do agencji w formie pisemnej, elektronicznie lub telefonicznie w liczbie kilkudziesięciu rocznie.

Z uwagi na brak szczegółowej wykładni prawa w przedmiotowym zakresie agencja wskazuje, iż decyzja w zakresie konieczności opiniowania danego programu polityki zdrowotnej leży w gestii danej JST. Powinna ona ocenić, czy zmodyfikowany projekt swoją treścią jest spójny z pierwotną wersją programu, a naniesione zmiany nie zmieniają znacząco jego założeń. 
Niemniej mając na uwadze analizę zapytań i wątpliwości oraz uwag JST kierowanych do AOTMiT, można wskazać najistotniejsze i najczęściej poruszane kwestie w zakresie zmian/wdrażania/realizacji PPZ.

Jedno z najczęściej zadawanych pytań dotyczy zmiany liczebności populacji. Agencja, odnosząc się do powyższej kwestii, wskazuje, iż w sytuacji zmiany liczebności populacji docelowej nie jest wymagana ponowna opinia prezesa AOTMiT. Należy jednak wziąć pod uwagę, iż zmiana liczebności populacji wpływa na zaplanowany budżet, tym samym przy zmianie liczebności populacji konieczna jest również modyfikacja budżetu. Ponadto AOTMiT podkreśla, że w przypadku zmniejszenia populacji $\mathrm{w}$ trakcie realizacji projektu wątpliwa jest zasadność jego realizacji i dalsze wydatkowanie środków z uwagi na fakt, że program uznaje się za efektywny przy przebadaniu populacji na poziomie $70 \%$.

Często pojawiają się pytania dotyczące zmiany przedziału wiekowego populacji docelowej objętej programem. Warto zaznaczyć, iż rozszerzenie/zawężenie przedziału wiekowego grupy docelowej wymaga ponownej opinii prezesa AOTMiT z uwagi na fakt, iż zmiana ta może wpływać na zasadność realizacji danego programu.

W zakresie pytań dotyczących interwencji w sytuacji zmiany rodzaju i zakresu badania w opinii AOTMiT konieczna jest ponowna ocena, gdyż może ona mieć wpływ na zasadność realizacji danego programu.

W przypadku kwestii odnoszącej się do modyfikacji ścieżki terapeutycznej zmiana kolejności badań lub konsultacji, które warunkują postawienie diagnozy lub przebieg leczenia, skutkuje koniecznością wystąpienia do AOTMiT o ponowne wydanie opinii. Natomiast w przypadku świadczeń niepołączonych z sobą ciągiem przyczynowo-skutkowym nie ma konieczności wydawania ponownej opinii prezesa AOTMiT.

Modyfikacje budżetu programu dotyczące zmiany wyceny badań/świadczeń - zmiana cen poszczególnych interwencji nie wymaga ponownego opiniowania PPZ przez AOTMiT. Analogicznie niedoszacowanie kosztów poszczególnych działań zaplanowanych w ramach PPZ - zmiana kosztów badań, wynagrodzeń, działań edukacyjnych, akcji informacyjnej również nie wymaga ponownego opiniowania PPZ.

Jeśli chodzi o zmiany w zakresie warunków realizacji w przypadku wydłużenia/zmiany terminu realizacji projektu, nie jest konieczne ponowne opiniowanie programu przez AOTMiT. Gdy nastąpi przerwa w realizacji programu między jego zakończeniem a kontynuacją, dopuszcza się możliwość kontynuacji programu w niezmienionym kształcie, jeżeli od jego zakończenia do ponownej realizacji nie upłynął okres dłuższy niż dwa lata. Podobnie w przypadku przerwy w realizacji programu między otrzymaniem opinii prezesa AOTMiT a wdrożeniem do realizacji także dopuszcza się możliwość realizacji programu w niezmienionym kształcie, jeżeli od jego zaopiniowania do realizacji nie upłynął okres dłuższy niż dwa lata.

Analiza zapytań dotyczących programów w trakcie realizacji wskazuje, że najczęściej dotyczą one PPZ szczepionkowych, co być może jest związane z faktem, iż taki rodzaj PPZ jest najczęściej realizowany przez JST. Jako przykład można tu wskazać programy szczepienia HPV. Najczęściej JST mają wątpliwości co do konieczności przygotowania nowego projektu PPZ w razie kontynuacji programu, rozszerzenia populacji na przykład o grupę chłopców, zmiany rodzaju preparatu szczepionkowego czy też zmiany kosztów programu. W odpowiedzi na powyższe AOTMiT wskazuje, że jeżeli planowane zmiany są zgodne z najnowszymi wytycznymi w przedmiotowym zakresie oraz nie wykraczają poza sugestie wskazywane w aktualnych opiniach prezesa agencji dotyczących przedmiotowego problemu zdrowotnego, w ocenie agencji nie wymagają one ponownego opiniowania. Nie ma jednak zdefiniowanego szczegółowego katalogu zmian, które można wprowadzać w realizowanych PPZ. Tym samym wątpliwości w tym zakresie rozpatrywane są indywidulanie.

Reasumując, wprowadzenie wszelkich zmian w PPZ powinno zostać zweryfikowane pod kątem ich zgodności z obowiązującymi przepisami prawa i opiniami prezesa agencji, a w razie potrzeby wyjaśniane na poziomie agencji.

Opinia prezesa agencji w sprawie projektu PPZ sporządzana jest według kryteriów wskazanych w ustawie o świadczeniach. Przedmiotem oceny są poszczególne elementy projektu PPZ (planowanie programu, opis problemu zdrowotnego i sytuacji epidemiologicznej, określenie celów i mierników efektywności, charakterystyka populacji docelowej i planowanych interwencji, opis monitorowania i ewaluacji programu, odniesienie do trwałości efektów zdrowotnych, planowanie budżetu i kosztów, opis organizacji programu). Ocena PPZ jest przeprowadzana przy wykorzystaniu narzędzia, jakim jest ocena technologii medycznych (ang. Health Technology Assessment, HTA), mająca zastosowanie w procesach decyzyjnych dotyczących finansowania technologii medycznych, zarówno lekowych, jak i nielekowych. Jest to proces naukowy, oparty na systematycznie zebranych, wiarygodnych, najlepszych dostępnych dowodach naukowych, odbywający się na podstawie opracowanych wytycznych. Stanowi on obiektywną i krytyczną ocenę, co ma na celu zapewnienie wysokiej jakości i wiarygodności przeprowadzanych analiz. Ponadto jest odpowiedzią na oczekiwania $\mathrm{w}$ zakresie przygotowywania analiz przy wykorzystaniu narzędzi, które wspierałyby podejmowanie decyzji dotyczących racjonalnego wydatkowania środków finansowych. Ma to istotne znaczenie w kontekście rosnących w czasie potrzeb zdrowotnych oraz kosztów opieki zdrowotnej przy ograniczonych zasobach finansowych.

Z doświadczenia agencji wynika, że wykorzystanie narzędzia w postaci HTA w trakcie projektowania PPZ jest niewystarczające. JST w trakcie opracowywania projektów PPZ nie przeprowadzają przeglądu dowodów naukowych w zakresie problemów zdrowotnych lub przeprowadzają je w sposób nieprawidłowy. Może to wynikać z braku odpowiedniej wiedzy i umiejętności korzystania z narzędzia HTA przez osoby odpowiedzialne za tworzenie projektów PPZ, jak również ze względu 
na ograniczone środki finansowe, jakie samorządy przeznaczają na opracowanie projektów PPZ. Prezes agencji w opiniach dotyczących PPZ podkreśla, że zaplanowane interwencje powinny korespondować z dowodami naukowymi, mieć potwierdzoną skuteczność i bezpieczeństwo, jak również być skierowane do właściwej, wskazanej w rekomendacjach i wytycznych klinicznych populacji docelowej. Ważnym aspektem związanym z wykorzystaniem oceny technologii medycznych jest także możliwość oceny efektywności kosztowej planowanych działań.

Ponadto dokonując analizy w kontekście poszczególnych szczebli samorządów terytorialnych, należy zwrócić uwagę na brak kompleksowego podejścia do projektowania, wdrażania i realizacji PPZ na wszystkich poziomach administracyjnych i organizacyjnych JST (gmina, powiat, województwo). Należy zaznaczyć, że polityka zdrowotna na poszczególnych szczeblach administracyjno-organizacyjnych wymaga zbierania danych na temat potrzeb zdrowotnych ludności oraz szczegółowych analiz epidemiologicznych na każdym poziomie projektowania programów odpowiednio do zdiagnozowanych problemów, koordynowania działań na wszystkich poziomach, na przykład przez tworzenie nowych lub $\mathrm{w}$ ramach realizacji istniejących podmiotów w formie tak zwanych centrów zarządzania zdrowiem. Kwestia zarządzania ochroną zdrowia na danym terenie powinna zostać skoordynowana co najmniej na poziomie powiatu.

Jak wspomniano wcześniej, istotnym aspektem związanym $\mathrm{z}$ realizacją PPZ jest monitorowanie i ewaluacja PPZ w celu oceny rzeczywistej efektywności działań i ich wpływu na zdrowie populacji. Zmiany ustawowe obligują JST do sporządzania raportu końcowego z realizacji PPZ. Wzór raportu końcowego i opis sposobu jego sporządzania $\mathrm{z}$ realizacji PPZ określa rozporządzenie ministra zdrowia. Zgodnie $\mathrm{z}$ treścią rozporządzenia $\mathrm{w}$ raporcie końcowym należy opisać, czy założony cel główny oraz cele szczegółowe zostały osiągnięte, a także w jakim stopniu nastąpiła realizacja poszczególnych celów ze wskazaniem przyczyn, dla których niemożliwa była ewentualna pełna realizacja. Opis stopnia realizacji celów powinien uwzględniać informacje na temat wartości mierników efektywności realizacji programu polityki zdrowotnej. W zakresie monitorowania w przypadku PPZ, których realizację rozpoczęto 30 listopada 2017 roku lub po tym dniu, należy wskazać liczbę osób zakwalifikowanych do udziału w PPZ, a także liczbę osób, które nie zostały objęte jego działaniami z przyczyn zdrowotnych lub z innych powodów (ze wskazaniem tych powodów), liczbę osób, które $\mathrm{z}$ własnej woli zrezygnowały w trakcie realizacji PPZ. W przypadku programów, których realizację rozpoczęto przed 30 listopada 2017 roku, dane wskazane w zdaniu poprzedzającym należy podać, o ile są dostępne. Należy opisać wyniki przeprowadzonej oceny jakości, w tym przedstawić zbiorcze wyniki, na przykład wyrażony w procentach stosunek opinii pozytywnych do wszystkich wypełnionych przez uczestników PPZ ankiet satysfakcji z udziału w programie polityki zdrowotnej. W przypadku programów polityki zdrowotnej, dla których okres realizacji został określony na czas dłuższy niż jeden rok, powinno się przedstawić wyniki monitorowania $\mathrm{z}$ podziałem na poszczególne lata realizacji. W zakresie ewaluacji należy ustosunkować się do efektów zdrowotnych uzyskanych i utrzymujących się po zakończeniu PPZ, między innymi na podstawie wcześniej określonych mierników efektywności odpowiadających celom PPZ. W zależności od jego charakteru należy przedstawić rezultaty możliwe do oceny w momencie składania raportu końcowego z realizacji PPZ (krótko- i długoterminowe). Trzeba przedstawić poniesione koszty jednostkowe w przeliczeniu na pojedynczego uczestnika PPZ, tam gdzie każdemu oferowany był dokładnie ten sam zakres interwencji. W programach złożonych, zakładających wieloetapowość interwencji, należy przedstawić koszty w rozbiciu na poszczególne świadczenia zdrowotne, które były oferowane w ramach PPZ. Należy opisać trudności, które zostały zweryfikowane w trakcie jego realizacji, oraz sposoby ich rozwiązania. Trzeba też opisać krytyczne aspekty, przez które planowane interwencje w ramach PPZ lub część tych interwencji nie mogły być zrealizowane. Zgodnie z zapisami ustawy o świadczeniach dane zawarte $\mathrm{w}$ raportach końcowych z realizacji PPZ będą stanowiły dla AOTMiT punkt wyjścia do dalszej analizy efektywności PPZ zarówno w skali całego kraju, jak i w odniesieniu do poszczególnych JST w krótko- i długoterminowej perspektywie czasu.

Kolejną ważną kwestią związaną z PPZ jest także wymiana wiedzy i doświadczeń między poszczególnymi JST na temat realizowanych i zakończonych PPZ. Warto zachęcać JST do opisywania i przedstawiania rezultatów realizacji PPZ jako przykładu aktywności i działań samorządów w zakresie zadań z ochrony zdrowia oraz dzielenia się doświadczeniami. Jedną z możliwości promowania PPZ jest organizacja konkursów na najlepsze PPZ. Jako przykład można wskazać podjętą wspólnie przez redakcje Portalu Samorządowego, portalu i magazynu „Rynek Zdrowia” wraz z wydawcą - Grupą PTWP inicjatywę organizacji konkursu „Zdrowy samorząd”, która miała swój początek w 2018 roku. Głównym celem konkursu jest wybór i nagrodzenie JST wszystkich poziomów, które w sposób najbardziej skuteczny realizują zadania związane z promocją zachowań prozdrowotnych, edukacją zdrowotną i profilaktyką wybranych schorzeń i/lub ich czynników ryzyka, między innymi w ramach PPZ. Programy są oceniane przez Radę Konsultacyjną Konkursu, w której skład wchodzą przedstawiciele między innymi instytucji centralnych i uczelni medycznych. W trakcie I edycji konkursu w 2018 roku do oceny wpłynęło 160 projektów zgłoszonych przez 60 samorządów. W 2019 roku do II edycji 82 samorządy zgłosiły do oceny 179 programów zdrowotnych [5].

W kontekście oceny efektywności realizowanych PPZ oraz ich długofalowego wpływu na zdrowie populacji zasadne wydaje się zachęcanie samorządów do tworzenia publikacji o charakterze naukowym na podstawie 
analizy danych zbieranych w trakcie i po realizacji programu, na przykład we współpracy ze środowiskami akademickimi i eksperckimi. Celem powyższych działań jest wymiana wiedzy i doświadczeń między różnymi środowiskami, co z kolei może się przełożyć na tworzenie projektów o coraz lepszej jakości.

Odnosząc się do kwestii związanych z czasem trwania procesu oceny projektów PPZ, należy wskazać, iż niektóre JST zwracają uwagę, że dwumiesięczny termin oczekiwania na opinię prezesa agencji jest zbyt długi, a w przypadku uzyskania opinii negatywnej ulega dalszemu wydłużeniu o czas konieczny do ewentualnej korekty projektu PPZ i ponownego opiniowania. Potencjalne zmiany w zakresie skrócenia czasu na ocenę PPZ wymagają korekt w zapisach ustawy o świadczeniach.

Kolejną kwestią wymagającą analizy jest zasadność przeprowadzania ponownej oceny i opiniowania projektu, który uzyskał negatywną opinię prezesa agencji. Należy podkreślić jednak pewnego rodzaju dwuznaczność odbioru negatywnej opinii prezesa agencji. Taka opinia może mieć charakter oceny, która nie neguje istoty projektu PPZ, ale uniemożliwia wdrożenie i realizację PPZ W zaproponowanej formie z uwagi na przykład na liczne błędy, nieprecyzyjne, niespójne zapisy, jak również braki w poszczególnych elementach programu. W przypadku tak skonstruowanej opinii JST mogą dokonać odpowiednich zmian w projekcie, zgodnie z uwagami i zastrzeżeniami wskazanymi w opinii i przesłać projekt do ponownego opiniowania. Natomiast drugi wymiar negatywnej oceny jest związany z negacją samej istoty projektu PPZ w kontekście rozpatrywanego problemu zdrowotnego, planowanych interwencji i populacji docelowej programu, które to elementy nie znajdują uzasadnienia lub są niejednoznacznie oceniane w odnalezionych dowodach naukowych. W przypadku tak wybrzmiewającej oceny wydaje się niezasadne kierowanie do ponownej oceny projektu PPZ bez dokonania dogłębnej analizy i zweryfikowania podejścia do planowanych działań.

Wychodząc naprzeciw oczekiwaniom JST oraz biorąc pod uwagę dotychczasowe doświadczenia związane z realizacją PPZ, w znowelizowanej ustawie o świadczeniach pojawiły się zapisy, w których agencja z własnej inicjatywy lub $\mathrm{z}$ inicjatywy ministra właściwego do spraw zdrowia dokonuje okresowej weryfikacji założeń zgromadzonych projektów programów polityki zdrowotnej i na podstawie tej weryfikacji przygotowuje raport w sprawie zalecanych technologii medycznych, działań przeprowadzanych w ramach PPZ oraz warunków realizacji tych programów dotyczących danej choroby lub danego problemu zdrowotnego i wydaje rekomendację $\mathrm{w}$ sprawie zalecanych technologii medycznych, działań przeprowadzanych w ramach PPZ oraz warunków. Warto podkreślić, iż obecnie agencja jest w trakcie opracowywania wyżej wymienionych raportów i rekomendacji między innymi w odniesieniu do profilaktyki grypy sezonowej w populacji osób w wieku 65 lat i więcej oraz profilaktyki zakażeń wirusem brodawczaka ludzkiego (HPV) w formie szczepień przeprowadzanych w populacji pediatrycznej.

\section{Podsumowanie}

Opieka zdrowotna wysokiej jakości to taka, w której zasoby medyczne, kadrowe, infrastrukturalne i finansowe są zorganizowane w możliwie najbardziej efektywny sposób. Oznacza to działania mające na celu zaspokojenie potrzeby społeczeństwa w zakresie profilaktyki, promocji zdrowia, diagnostyki, leczenia i rehabilitacji oraz pewność, że opieka ta spełnia wymagania bezpieczeństwa, skuteczności i efektywności. Działalność AOTMiT w zakresie oceny PPZ wpisuje się w system ochrony zdrowia, którego jednym z celów jest zapewnienie efektywnej i zgodnej ze standardami jakości opieki zdrowotnej.

Zadania JST z zakresu zdrowia publicznego regulowane są kilkoma aktami legislacyjnymi. Najbardziej podstawowa w zakresie omawianych zagadnień wydaje się ustawa o zdrowiu publicznym, lecz określa ona jedynie zakres i zbiór wyżej wymienionych zadań, pozostawiając otwarty katalog inicjatyw, które mogą zostać podjęte, natomiast poszczególne zadania są określone w innych aktach prawnych, na przykład w ustawie o świadczeniach czy w ustawie o wychowaniu w trzeźwości. Ustawa o świadczeniach nakłada sztywny szablon PPZ, jak również wiążące zastosowanie się do uwag w opinii prezesa AOTMiT. W przypadku innych możliwych form realizacji zadań z zakresu zdrowia publicznego brak jest tak szczegółowych zapisów. Wydaje się zatem, że programy zbliżone do siebie merytorycznie mogą być oceniane w różny sposób, przy czym w poszczególnych trybach postępowania mogą być potraktowane jako możliwe do realizacji lub też odrzucone. Ta nierówność w ocenie i dosyć szeroki wybór trybów realizacji zadań z zakresu zdrowia publicznego mogą prowadzić do nadużyć i realizowania działań nieefektywnych kosztowo i nieprzekładających się na efekty zdrowotne w społeczeństwie. Wydaje się, że istotne jest uporządkowanie systemu mające na celu jasny podział kompetencji, w których to dane organy będą odpowiedzialne odpowiednio za dostarczanie proponowanych rozwiązań, nadzór nad ich realizacją, współpracę przy realizacji, monitorowanie i ewaluację oraz finansowanie.

Analizując poszczególne akty prawne oraz dokumenty, nasuwa się wniosek, że działania z zakresu zdrowia publicznego prowadzi się w całym kraju, ograniczone są jednak dane pozwalające na analizę ich skuteczności oraz ocenę, czy w jakikolwiek sposób przekładają się one na efekty zdrowotne.

Podsumowując, tylko działania realizowane w ramach ustawy o świadczeniach podlegają opiniowaniu przez agencję, a tym samym sprawdzeniu, czy mają one odzwierciedlenie w dowodach naukowych. Wszystkie pozostałe działania mogą być realizowane z wykorzystaniem modelowych rozwiązań, na przykład Głównego Inspektora Sanitarnego (GIS) w zakresie opracowywania i wdrażania programów zdrowotnych/edukacyjnych (między innymi programów szkolnych dotyczących zdrowego stylu życia, uzależnień, ryzykownych zachowań) czy Państwowej Agencji Rozwiązywania Problemów Alkoholowych (PARPA) w zakresie rekomendacji 
programów dotyczących uzależnień i zdrowia psychicznego oraz merytorycznego nadzoru nad pracą gminnych i miejskich komisji rozwiązywania problemów alkoholowych lub też mogą być realizowane bez jakiejkolwiek weryfikacji.

Eksperci wskazują, że samorządowe programy zdrowotne są bardzo potrzebne. Zgodnie z opiniami ekspertów sukces wieloletnich PPZ na przykład z zakresu szczepień to nie tylko zwiększenie dostępności do usług medycznych, lecz także wzrost poziomu wiedzy na temat dominujących problemów zdrowotnych.

Pozostaje pytanie, czy PPZ powinny stać się obowiązkowym zadaniem samorządów, czy też mają stanowić jedynie działania uzupełniające $\mathrm{w}$ systemie zdrowia publicznego. Kolejny aspekt wskazywany przez ekspertów dotyczy odniesienia i adekwatności działań podejmowanych przez samorządy do rzeczywistych danych epidemiologicznych. Samorządy, realizując zadania z zakresu zdrowia publicznego, często wykraczają poza świadczenia ujęte w koszyku gwarantowanym, na przykład przez realizację programów szczepień. Eksperci stawiają także pytanie, czy aktywność samorządów w tym zakresie nie powinna iść bardziej w stronę profilaktyki czynników ryzyka głównych zagrożeń zdrowotnych, czyli chorób onkologicznych i kardiologicznych. Powyższe kwestie stanowią przedmiot dyskusji nad przyszłym kierunkiem rozwoju PPZ.

Eksperci podkreślają także, że samorządy wymagają wsparcia nie tylko finansowego, lecz także, a może przede wszystkim, dotyczącego świadomości i merytorycznej podbudowy wskazującej, w jaki sposób realizować programy zdrowotne, także te trudniejsze i bardziej złożone niż obejmujące szczepienia.

Reasumując, jak wskazują eksperci, zaspokajanie potrzeb zdrowotnych wydaje się procesem w coraz większym stopniu świadomym i analitycznym, a coraz mniej spontanicznym. Wzrost świadomości takiego podejścia, rozwój metodologii oraz zasobów informacyjnych stają się właściwym kierunkiem w celu realizacji tego zadania.

\section{Piśmiennictwo}

1. Skóbel B., Rudka R., Programy polityki zdrowotnej bez tajemnic, Związek Powiatów Polskich, Warszawa 2016.

2. Cianciara D., Rdzany R., Planowanie samorzadowych programów zdrowotnych. Część III, Monitorowanie i ewaluacja, „Hygeia Public Health” 2015; 50 (1): 97-103.

3. Domagała A., Dubas-Jakóbczyk K., Topór-Mądry R., Ewaluacja programów zdrowotnych - od teorii do praktyki, „Public Health Forum” 2015; 2: 108-114.

4. Dubas-Jakóbczyk K., Domagała A., Stymulowanie realizacji samorzadowych programów zdrowotnych $-w$ świetle doświadczeń międzynarodowych. Rozdział 12, Regionalizacja polityki zdrowotnej $w$ Polsce, red. nauk. R. Holly, Uniwersytet Medyczny w Łodzi, Szkoła Główna Handlowa w Warszawie, Łódź-Warszawa 2016: 249.

5. https://www.portalsamorzadowy.pl/konkurs/zdrowy-samorzad-2019,47/ (dostęp: 29.08.2019).

\section{Akty prawne i dokumenty}

6. Ustawa z dnia 27 sierpnia 2004 roku o świadczeniach opieki zdrowotnej finansowanych ze środków publicznych (Dz.U. z 2019 roku poz. 1373).

7. Rozporządzenie Ministra Zdrowia z dnia 22 grudnia 2017 roku w sprawie wzoru programu polityki zdrowotnej, wzoru raportu końcowego z realizacji programu polityki zdrowotnej oraz sposobu sporządzenia projektu programu polityki zdrowotnej i raportu końcowego z realizacji programu polityki zdrowotnej (Dz.U. z 2017 roku poz. 2476).

8. Najwyższa Izba Kontroli, „Informacja o wynikach kontroli w zakresie Realizacja programów polityki zdrowotnej przez jednostki samorządu terytorialnego", Nr ewidencyjny: P/15/063. Data publikacji: 13.10.2016, 10:10. Dział tematyczny: zdrowie.

9. Ministerstwo Zdrowia, „Informacja o zrealizowanych lub podjętych zadaniach $\mathrm{z}$ zakresu zdrowia publicznego $\mathrm{w}$ roku 2016 i 2017" opracowana zgodnie z art. 12 Ustawy z dnia 11 września 2015 roku o zdrowiu publicznym (Dz.U. z 2018 roku poz. 1492), Ministerstwo Zdrowia, Warszawa 2018. 